\title{
LOS ORÍGENES DE LA REVOLUCIÓN INDUSTRIAL: UN HOMENAJE A ERIC J. HOBSBAWM
}

Iñaki Vázquez Larrea

Universidad Pública de Navarra

http://dx.doi.org/10.5209/NOMA.56937

Entre el gran elenco de historiadores sociales desde los de abajo (Christopher Hill, E.P. Thompson o George Rudé) destacó la figura de Eric J. Hobsbawm. La reimpresión reciente de una de sus obras fundamentales En torno a los orígenes de la revolución industrial sirve de homenaje al que fuera profesor de Historia en el Birkbeck College y una figura clave de la Historia social británica.

Podríamos señalar, en primer lugar, que la Revolución industrial del siglo XVIII, vino precedida por una gran recesión en el siglo XVII, por la que el Mediterráneo dejo de ser el más importante centro político y económico, y cultural para pasar a ser un pantano empobrecido. Época de profundo malestar social, la crisis general produjo su hecho más incisivo y dramático en la revolución política burguesa inglesa, que llevó a Samuel Fortrey a señalar en 1663 que Inglaterra sería la nación más floreciente del futuro.

No obstante, y por paradójico que pueda resultar, la crisis no generó un súbito cambio en las estructuras sociales que facilitase una ulterior acumulación de capital, la burguesía no dejó de ser periférica y parasitaria, pero si dos condicionantes a la salida de la crisis que permitieron su eclosión ulterior. En primer lugar, el mercantilismo gubernamental, al estilo de Colbert, que facilitó el desarrollo de la industria nacional:

"La transformación fue tan rápida, que para la década de 1690, Inglaterra parecía efectivamente en el umbral de la revolución industrial. Además, esta transformación en la posición mundial de la economía británica no se debió solamente a desarrollos económicos espontáneos, sino también a una importante revolución en su política que subordinó en adelante todos los otros fines a un mercantilismo agresivo tendiente a la acumulación de capital y beneficios" (Eric J. Hobsbawm, En torno a los orígenes de la revolución industrial, p. 95)

En segundo lugar, el flujo creciente del comercio colonial que incentivo sobremanera la inversión productiva en el área agrícola e industrial.

"El mayor logro de la crisis del siglo XVII fue la creación de una nueva forma de colonialismo. Como hemos visto, bajo el sistema colonial del siglo XVI-que los holandeses adoptaron sin modificarlo sustancialmente- 
el mercado colonial para las manufacturas internas tenía escasa importancia, pese a que una gran empresa colonial o el Estado, considerado como empleador y como comprador de bienes de capital y de bienes de consumo, estimulaba la economía interna al mismo tiempo que producía beneficios para la acumulación. Entre 1660 y 1681, se dice que el tráfico de las Indias Orientales alcanzó sólo a la doceava parte del tráfico total holandés. Los comerciantes parecían demostrar escaso entusiasmo por la demanda del consumidor de Latinoamérica. Sin embargo, las posibilidades de los mercados coloniales se transformaron con el establecimiento de las plantaciones coloniales que producian sin una sistemática restricción del producto total y de las colonias europeas de contrato. También en este caso la mitad del siglo XVII marca un punto crucial" (Eric J. Hobsbawm, En torno a los orígenes de la revolución industrial, p. 68).

El autor, por último, desmitifica el paradigma Schumpeteriano, centrado en la innovación empresarial, el rostowniano, que pone el acento en la innovación técnica y el ideologismo calvinista weberiano, para poner el acento en la contingencia histórico -social expansiva mercantil, a la hora de entender los condicionantes pre-capitalistas en los albores de la Revolución Industrial:

"El árbol de la expansión capitalista moderna creció en una determinada región de Europa, pero sus raíces extrajeron su alimento de un área de intercambio y acumulación primitiva mucho más amplia, que incluía tanto las colonias de ultramar ligadas por vínculos formales como las "economías dependientes" de Europa Oriental, formalmente autónomas" (Eric J. Hobsbawm, En torno a los orígenes de la revolución industrial, p. 118).

\section{BIBLIOGRAFÍA:}

HOBSBAWM, E.J: En torno a los orígenes de la revolución industrial, Siglo XXI, Madrid, 2017. 